\title{
REAKCJA INWESTORÓW GIEŁDY HISZPAŃSKIEJ NA ZAMKNIĘCIE GRANIC. WERYFIKACJA ZA POMOCA METODYKI ANALIZY ZDARZEŃ
}

\author{
Kamila Ulmann ${ }^{*}$, Filip Roszkowski ${ }^{* *}$
}

$\underset{\substack{\text { Member since } 2021 \\ \text { JM151502 }}}{\mathbf{C} \mid \mathbf{O} \mathbf{P}}$

\section{cc) creative}

https://doi.org/10.18778/2391-6478.4.32.06

\section{TESTING THE REACTION OF SPANISH EXCHANGE MARKET WITH THE USE OF EVENT STUDY}

\section{Abstract}

The purpose of the article/hypothesis: The aim of the article is to examine the significance of the reaction of stock exchange investors in that country to the publication of information about the reintroduction of border controls in order to limit the movement of people, especially foreigners. The article discusses issues related to economics and behavioral finance, paying special attention to the irrationality of decisions, discussed by many authors, under the influence of various factors. Methodology: In the case of the empirical study, event analysis methodologies were applied, using abnormal and cumulative abnormal rates of return.

Results of the research: The results of a detailed analysis of events, based on overnormative singleperiod logarithmic rates of return and cumulative over-normative single-period logarithmic rates of return for an event, showed an interesting case contradicting the thesis on irrationality of investor behavior in the capital market, while questioning the efficient market hypothesis.

Keywords: event study, behavioral economics, behavioral finance, irrationality, capital market.

JEL Class: C40, C12, G02, D53.

\footnotetext{
* Licencjat, Wydział Ekonomiczny, Wydział Zarządzania, Uniwersytet Gdański, e-mail: kamila971971@gmail.com https://orcid.org/0000-0003-4141-8932

** Licencjat, Wydział Ekonomiczny, Uniwersytet Gdański, e-mail: filip.ros700@gmail.com https://orcid.org/0000-0001-6670-6223
} 


\section{WSTĘP}

Wirus SARS-CoV-2 powodujący COVID-19 niewątpliwie odcisnął wyraźne piętno na światowej gospodarce wraz ze swoim pojawieniem się i szybkim rozprzestrzenianiem. Negatywny wpływ wirusa objawił się przede wszystkim w postaci gwałtownego zmniejszenia się aktywności gospodarczej w wielu rejonach świata. W początkowym okresie szczególnie w Chinach, następnie rozprzestrzenił się na powiązane gospodarki azjatyckie i dalej. Doprowadziło to bezpośrednio do zaburzenia pracy łańcuchów dostaw, wpływając tym samym drastycznie na gospodarki europejskie oraz amerykańską, które również po krótkim czasie same musiały podjąć walkę z wirusem bezpośrednio na swoim terenie.

Wpływ wirusa nie mógł ominąć również rynków kapitałowych, których reakcje stanowią odzwierciedlenie zachowań i reakcji inwestorów na wieści o przedostawaniu się wirusa do kolejnych państw oraz o pojawiających się restrykcjach, wpływających na wiele branż, takich jak turystyka, transport i wiele innych, pogarszając tym samym jakość otoczenia gospodarczego i instytucjonalnego. Wspomniane działania inwestorów mogą być ciekawym obiektem badania, szczególnie biorąc pod uwagę dorobek ekonomii oraz finansów behawioralnych, zwracających uwagę na nieracjonalność zachowań podmiotów gospodarczych lub inwestorów, pod wpływem konkretnych wydarzeń. W tym celu pomocna okazuje się, opracowana lata temu, metoda analizy zdarzeń, która wskazać może istotność wspomnianej reakcji (lub brak istotnej reakcji) na przykładowo upublicznioną informację.

Celem niniejszego artykułu jest weryfikacja reakcji hiszpańskich inwestorów na informację o zamknięciu granic Hiszpanii, zaś postawioną hipotezą: reakcja inwestorów w Hiszpanii była statytystycznie istotna. Ma to bezpośredni związek z faktem, iż rynek kapitałowy (m.in. wartość notowań spółek) stanowi odzwierciedlenie zachowań inwestorów, w związku z czym przyjąć można, że globalna pandemia powinna wpłynąć na ich reakcję.

\section{BEHAWIORALNE MECHANIZMY PODEJMOWANIA DECYZJI INWESTYCYJNYCH}

Ekonomia behawioralna w XXI w. niewątpliwie staje się gałęzią ekonomii coraz bardziej respektowaną i rozszerzającą swój wpływ na jej główny nurt. Począwszy od przyznania w 2001 r. Nagrody Banku Szwecji im. Alfreda Nobla Danielowi Kahnemanowi (wraz z Vernonem L. Smithem, który z kolei zasłużył się w dziedzinie ekonomii eksperymentalnej), za wkład w rozwój psychologii ekonomicznej, czy odebranie tejże nagrody przez Richarda Thalera w 2017 r., w związku z poczynionym przez niego wkładem w rozwój finansów behawioralnych. Nie 
dziwi zatem fakt, iż metodologię i zakres zainteresowań ekonomii behawioralnej rozszerza się także na takie dziedziny, jak makroekonomia czy właśnie finanse.

Pewne fundamenty ekonomii behawioralnej wywodzi się już z teorii J.M. Keynesa, a ściślej mówiąc wprowadzone przez Keynesa pojęcie ,zwierzęcych instynktów" (Orlik, 2017). Keynes zwrócił uwagę, iż wbrew koncepcji homo oeconomicus ludzie często zachowują się nieracjonalnie, a ich działaniami kieruje nie zdrowy rozsądek i kalkulacja ekonomiczna, a uleganie emocjom i zachciankom (Keynes, 2011). Ułomności modeli ekonomicznych wykorzystujących koncepcję homo oeconomicus zauważył i w 2015 r. opisał R. Thaler (Thaler, 2018). Zwrócił on uwagę, iż ludzie w swoich decyzjach i osądach często nie kierują się wcale racjonalnym rozumowaniem czy dążeniem do ekonomicznej optymalizacji, a mimo to ekonomiści w swoich rozważaniach nie biorą pod uwagę takich zjawisk, jak błędy poznawcze, czy nadmierna pewność siebie, pomimo iż fenomeny te zauważył już A. Smith na długo przed Keynesem (Thaler, 2018).

W wyniku dotychczasowych badań opisano już wiele reguł wyjaśniających ludzkie zachowania, takich jak heurystyki wydawania sądów, wspomniane powyżej błędy poznawcze czy różnego rodzaju efekty psychologiczne. Jakie jednak mechanizmy odnoszą się bezpośrednio do podejmowania decyzji przez inwestorów? Jakie zjawiska psychologiczne przyczyniają się do pozytywnych, bądź negatywnych reakcji cen aktywów czy wartości indeksów giełdowych? Odpowiedzi na te pytania udziela dorobek finansów behawioralnych.

Finanse behawioralne wychodzą niejako naprzeciw sformułowanej przez E. Famę w 1970 r. hipotezie rynku efektywnego (HRE), którą Fama podzielił na wersję słabą, półsilną oraz silną. Zgodnie z wersją słabą, aktualne ceny aktywów stanowią doskonałe odzwierciedlenie pełnego wykorzystania informacji płynących z rynku, z uwzględnieniem informacji historycznych, zatem przeszłe ceny aktywów nie mogą stanowić wskaźnika, na podstawie którego można by było przewidzieć, jak ceny będą się kształtować w przyszłości. Nie miałoby wówczas sensu stosowanie analizy technicznej, jako narzędzia podejmowania decyzji inwestycyjnych. Wersja półsilna zakłada, że ceny szybko dostosowują się do płynących z rynku ogólnodostępnych informacji, co w konsekwencji oznacza, że dobrym wskaźnikiem dla podejmowania decyzji nastawionych na ponadprzeciętne zyski nie mogłaby być ani analiza techniczna, ani fundamentalna. Silna wersja tej hipotezy zakłada z kolei, że bieżące ceny aktywów stanowią odzwierciedlenie wszystkich informacji zarówno publicznych, jak i niepublicznych (Orlik, 2017). Według HRE wszelkie anomalie są na tyle nieliczne, że zostają zniwelowane, a jednostki zachowujące się w sposób nieracjonalny niwelują swoje zachowania nawzajem. Niebezzasadne zatem byłoby stwierdzenie, że zgodnie z HRE (zwłaszcza z jej silną wersją) na rynku kapitałowym nie występuje asymetria informacji, zaś inwestorzy w pełni wykorzystując dostępne informacje zachowują się w sposób całkowicie racjonalny i maksymalizują swoją użyteczność (Fama, 1970). 
Teoria finansów behawioralnych podważa to stwierdzenie, zaprzeczając zarówno racjonalności inwestorów, jak i w konsekwencji znikomemu wpływowi na ceny aktywów, jednostek postępujących w sposób nieracjonalny (Zielińska i Ostrowska, 2013). Na taką nieefektywność rynku wskazywał już sam J.M. Keynes, na długo zanim HRE została w ogóle sformułowana, o czym wspomniano powyżej. Zwrócił on uwagę na nadmierne, nieuzasadnione w jego mniemaniu fluktuacje na rynku kapitałowym. R. Thaler wśród pierwszych efektów stanowiących swego rodzaju zanegowanie HRE wskazuje właśnie keynesowski tzw. „konkurs piękności”. Jest to zjawisko, na podstawie którego Keynes chciał zobrazować regułę podejmowania decyzji inwestycyjnych, którą według niego posługiwali się niedoświadczeni inwestorzy. Ogłaszany przez gazety konkurs, w którym czytelnicy wybierając kilka fotografii mieli wskazać, kto jest według nich najpiękniejszy. Zwycięzcą był ten, którego wybór najbardziej odzwierciedlał upodobania reszty czytelników. W efekcie czytelnicy zamiast wskazywać swoje upodobania próbowali odgadnąć upodobania pozostałych czytelników i na tej podstawie dokonać wyboru fotografii. Tak jak w eksperymencie myślowym Keynesa, inwestorzy, zamiast kierować się racjonalnymi przesłankami, wskazującymi, jak mogą kształtować się w przyszłości ceny aktywów, próbują odgadnąć jakie decyzje będą podejmowali pozostali inwestorzy, w ten sposób prognozując kształtowanie się poziomu cen (Thaler, 2018).

Bardziej współczesną teorią z dziedziny finansów behawioralnych, świadczącą o nieracjonalności zachowań podmiotów gospodarujących, jest opracowana przez D. Kahnemana i A. Tversky'ego teoria perspektywy (Kahneman i Tversky, 1979). Stanowi ona kolejną istotną przesłankę dla twierdzenia, iż podmioty gospodarujące nie podejmują decyzji w taki sposób, jak robi to homo oeconomicus, teoria ta zatem jest sprzeczna z teorią oczekiwanej użyteczności, a decyzje nie są podejmowane tylko w oparciu o średnie i wariancje stóp zwrotu (Schabek, 2016).

Teoria perspektywy wyróżnia dwa etapy podejmowania decyzji przez podmioty gospodarujące. Pierwszy etap to tzw. obróbka. W fazie obróbki następuje wstępne przeanalizowanie możliwych do podjęcia decyzji alternatywnych, pominięcie niewielkich prawdopodobieństw i wyodrębnienie wyniku uznanego za pewny oraz zakodowanie subiektywnego punktu stanowiącego o przypisaniu wyniku do zysku lub straty. Drugim etapem w teorii perspektywy jest z kolei faza oceny. Na tym etapie podmiot podejmujący decyzje ocenia wybrane alternatywy, wykorzystując do tego dwie funkcje. Pierwszą z nich jest funkcja ważąca prawdopodobieństwa - na jej podstawie następuje określenie wpływu prawdopodobieństw na ogólną wartość wyboru. Drugą jest funkcja oceny wyniku - na jej podstawie następuje przypisanie wynikom poszczególnych zdarzeń subiektywnie określonej wartości. Wysokość wartości stanowi kryterium podjęcia decyzji. Należy zaznaczyć, iż Kahneman i Tversky w wyniku swoich badań ustalili, że ból powodowany stratą jest około dwukrotnie bardziej odczuwalny, niż radość związana z odniesieniem zysku (Thaler, 2018). 


\section{BADANIE ZACHOWAŃ INWESTORÓW ZA POMOCA ANALIZY ZDARZEŃ - OPIS METODYKI}

Jedna z pierwszych prac dotyczących analizy zdarzeń pojawiła się za sprawą J. Dolleya, który na podstawie próby 96 splitów akcji na rynku amerykańskim między 1921 a 1931 r. zbadał momenty, w których występował wzrost i spadek cen (Kujawa i Ostrowska, 2016). Następnie, kamieniem milowym wykorzystywania analizy zadarzeń stała się praca E. Famy, Fishera, Jensena i Rolla z 1969. Autorzy ci uznawani są powszechnie za autorów metody (Perepeczo, 2010).

Obecnie autorzy bardzo często wykorzystują tę metodę w przypadku badań efektów finansowych, dotyczących fuzji i przejęć oraz generalnie do badania efektywności rynku kapitałowego. Innym zastosowaniem jest badanie efektów udostępnienia informacji o wydarzeniach mających miejsce w spółkach (takie wykorzystywanie tej metody ma miejsce głównie w badaniach z zakresu finansów behawioralnych), dotyczyć to może ogłoszenia informacji o dywidendzie, czy pierwszej emisji akcji i nie tylko (Perepeczo, 2010).

Warto również wskazać zastosowania metody analizy zdarzeń w licznych pracach empirycznych w tym zakresie. Jak już wspomniano, metodyka ta często wykorzystywana jest do analizy przejęć, czego dowodem są liczne prace z tym związane. Wśród autorów tego typu badań wymienić można przykładowo Mitchella i Stafforda (1998), którzy wykorzystali trzyletnie okno zdarzenia oraz model skorygowany o wielkość i B/M wraz z modelem Famy i Frencha do analiz fuzji oraz ofert przejęć. Innymi autorami badań z tego zakresu są Sudarsanam i Mahate (2003), którzy, podobnie, wykorzystali trzyletnie okno zdarzenia do weryfikacji istotności ofert przejęcia za pomocą modelu skorygowanego o średnią, rynek i wielkość i wskaźnik MTBV (wartości rynkowej do księgowej).

Do prawidłowego przeprowadzenia analizy zdarzeń konieczne jest ustalenie zdarzenia poddawanego analizie oraz zdefiniowanie czasu występowania - jest to tzw. okno zdarzenia, względem którego przeprowadzone zostaje badanie. W następnej kolejności niezbędnym jest określenie poziomu rzeczywistej i oczekiwanej stopy zwrotu (stopa odniesienia), ponadnormatywnej stopy zwrotu, okna estymacji, a w ostatnim etapie weryfikacja hipotez (Lisicki, 2018).

Analiza zdarzeń bywa nazywana również metodą ponadnormatywnych stóp zwrotu, właśnie ze względu na fakt, iż ocena dokonywana jest na podstawie różnic między wspomnianymi wcześniej stopami zwrotu: rzeczywistą stopą zwrotu $\mathrm{z}$ akcji, a jej oczekiwaną stopą w okresie $t \mathrm{z}$ waloru $i$ (Perepeczo, 2010). 
Dodatkowa, czyli ponadnormatywna stopa zwrotu wyliczana jest według następującej formuły (Kabaciński, 2013):

$$
A R_{i}=R_{i}-E(R)_{i}
$$

gdzie:

$A R$ - ponadnormatywna stopa zwrotu z waloru $i$,

$R$ - rzeczywista stopa zwrotu z waloru $i$,

$E(R)$ - oczekiwana stopa zwrotu z waloru $i$.

Dodatkowym elementem analizy zdarzeń może być również wyliczenie skumulowanych ponadnormatywnych stóp zwrotu, czyli $C A R$, które wylicza się za pomocą następującej formuly:

$$
C A R_{i, k-n}=\sum_{t=k}^{t=n} A R_{i, t},
$$

gdzie:

$C A R_{i, k-n}$ - skumulowana ponadnormatywna stopa zwrotu $\mathrm{z}$ akcji $i \mathrm{w}$ okresie od dnia $k$ do dnia $n$ (przykładowo od -2 do +2 , czyli obejmując dni przed zdarzeniem, zdarzenie oraz po nim),

$A R_{i, t}$ - nadzwyczajna stopa zwrotu $\mathrm{z}$ akcji $i \mathrm{w}$ dniu $t$.

\section{EMPIRYCZNE BADANIE ZACHOWAŃ INWESTORÓW GIEŁDY HISZPAŃSKIEJ W ZWIAZZKU Z ZAMKNIĘCIEM GRANIC HISZPANII}

W poniższym badaniu oczekiwane stopy zwrotu zostały wyliczone za pomocą indeksu giełdowego szerokiego rynku (IBEX) i są to jednookresowe logarytmiczne stopy zwrotu, natomiast rzeczywiste stopy zwrotu pochodzą z notowań 35 spółek z hiszpańskiego indeksu IBEX35 (indeks giełdowy grupujący 35 największych i najpłynniejszych spółek akcyjnych Giełdy Papierów Wartościowych w Madrycie) oraz podobnie, są to jednookresowe logarytmiczne stopy zwrotu. Skład indeksu jest następujący: Acciona, Acerinox, Actividades de Construcción y Servicios, SA, Aena, Amadeus, ArcelorMittal, Banco Bilbao Vizcaya Argentaria, Bankia, Bankinter, Banco Santander Central Hispano, CaixaBank, Cellnex Telecom, Cie Automotive SA, Enagás, ENCE Energia y Celulosa, Endesa, Ferrovial SA, Gamesa Technology Corporation, Grifols SA, IAG, Iberdrola, Inditex, Indra Sistemas, Inmob colonial, Mapfre, MEDIASET, Melia Hotels, Merlin Prosperties SA, Naturgy Energy, Red Eléctrica, Repsol YPF, Sabadell, Tec. Reunidas, Telefónica, Viscofan SA. 
W pracy posłużono się ponadnormatywną stopą zwrotu, czyli $A R$, oraz skumulowaną ponadnormatywną stopą zwrotu $(C A R)$ do weryfikacji postawionej hipotezy na temat reakcji inwestorów.

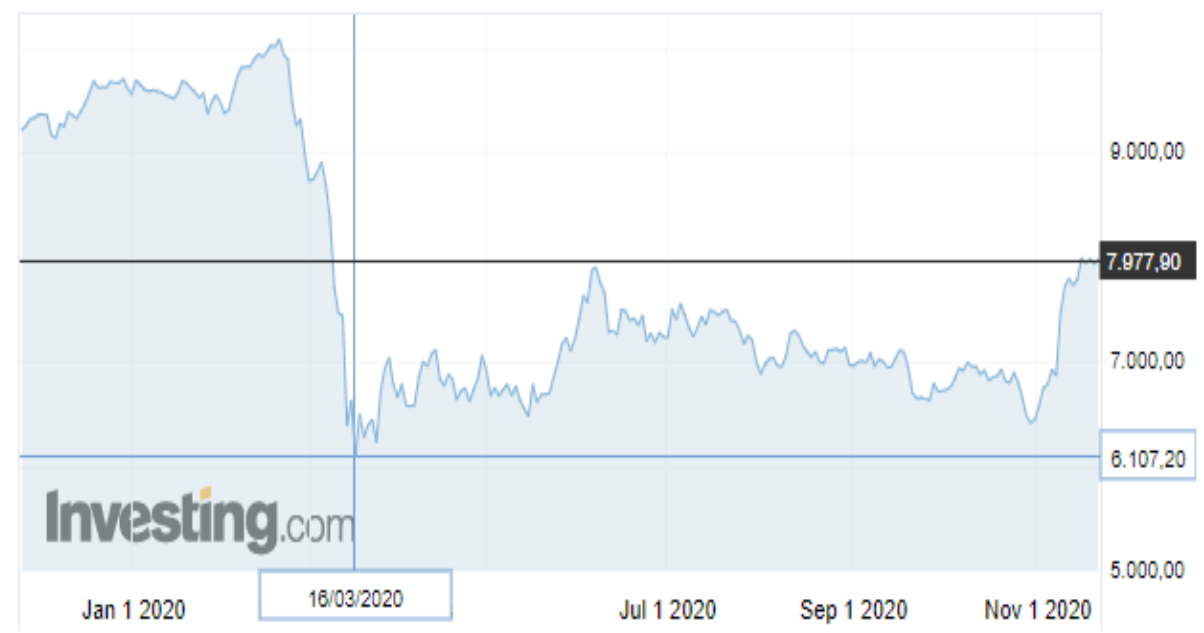

Rysunek 1. Wykres przedstawiający notowania indeksu giełdowego IBEX35

Źródło: Investing.

Rysunek 1 przedstawia kształtowanie się notowań indeksu giełdowego IBEX35 (indeks giełdowy grupujący 35 największych i najpłynniejszych spółek akcyjnych Giełdy Papierów Wartościowych w Madrycie). Widać wyraźnie, że zauważalna na długo przed 16 marca stabilizacja notowań indeksu uległa gwałtownej zmianie na rzecz trendu spadkowego, po którym ponownie, względnie szybko, notowania powróciły do stabilizacji. Na wykresie wskazano również 16 marca bieżącego roku, z uwagi na to, iż za dzień 0, czyli dzień zdarzenia, przyjęto właśnie 16 marca 2020 - dzień upubliczenia informacji o przywróceniu kontroli na granicach w celu ograniczenia wjazdów cudzoziemców. Za okno zdarzenia natomiast przyjęto 41 okres wokół dnia zdarzenia (czyli dzień zdarzenia, 20 dni przed nim oraz 20 dni po nim).

$\mathrm{W}$ tabeli 1 przedstawiono podstawowe statystyki opisowe dla ponadnormatywnych stóp zwrotu.

Wymienione parametry zostały wyliczone za pomoca programu formuł Excel. Wyliczono średnią (=ŚREDNIA()), wartość minimalną (min. wartość, $=\mathrm{MIN}()$ ), wartość maksymalną (max. wartość, =MAX()), odchylenie standardowe (odch. stand., =ODCH.STAND.POPUL), skośność (=SKOŚNOŚĆ()), kurtozę $(=\operatorname{KURTOZA}())$. 
Tabela 1. Statystyki opisowe dla dziennych ponadprzeciętnych stóp zwrotu obliczonych wokół dnia ogłoszenia informacji o zamknięciu granic Hiszpanii

\begin{tabular}{|c|c|c|c|c|c|c|c|c|c|}
\hline $\begin{array}{c}\text { Dzień } \\
\text { wokół } \\
\text { dnia } \\
\text { zdarzenia }\end{array}$ & Średnia & $\begin{array}{c}\text { Min. } \\
\text { wartość }\end{array}$ & $\begin{array}{c}\text { Max. } \\
\text { wartość }\end{array}$ & $\begin{array}{l}\text { Odch. } \\
\text { Stand. }\end{array}$ & Skośność & Kurtoza & SW & p-value & $\begin{array}{c}\text { Normalność } \\
\text { rozkładu }\end{array}$ \\
\hline 20 & 0,00 & $-0,07$ & 0,06 & 0,03 & $-0,52$ & 0,71 & 0,96 & 0,27 & $\mathrm{H} 0$ \\
\hline 19 & 0,00 & $-0,06$ & 0,06 & 0,03 & 0,26 & $-0,18$ & 0,99 & 0,93 & $\mathrm{H} 0$ \\
\hline 18 & 0,00 & $\begin{array}{l}-0,04 \\
\end{array}$ & 0,05 & 0,02 & 0,32 & $-0,86$ & 0,96 & 0,25 & $\mathrm{H} 0$ \\
\hline 17 & 0,00 & $-0,02$ & 0,04 & 0,01 & 0,82 & 0,64 & 0,95 & 0,10 & $\mathrm{HO}$ \\
\hline 16 & 0,01 & $-0,06$ & 0,11 & 0,04 & 0,57 & $-0,14$ & 0,96 & 0,23 & $\mathrm{H} 0$ \\
\hline 15 & 0,00 & $-0,05$ & 0,09 & 0,03 & 0,46 & $-0,55$ & 0,95 & 0,11 & $\mathrm{H} 0$ \\
\hline 14 & $-0,01$ & $-0,04$ & 0,04 & 0,02 & 0,53 & $-0,53$ & 0,95 & 0,13 & $\mathrm{H} 0$ \\
\hline 13 & 0,00 & $-0,03$ & 0,06 & 0,02 & 0,70 & 0,37 & 0,94 & 0,06 & $\mathrm{HO}$ \\
\hline 12 & 0,00 & $-0,05$ & 0,07 & 0,03 & 0,51 & 0,68 & 0,97 & 0,45 & $\mathrm{HO}$ \\
\hline 11 & 0,01 & $-0,05$ & 0,08 & 0,03 & 0,45 & $-0,55$ & 0,97 & 0,45 & $\mathrm{H} 0$ \\
\hline 10 & 0,00 & $-0,06$ & 0,07 & 0,03 & 0,37 & $-0,24$ & 0,96 & 0,18 & $\mathrm{H} 0$ \\
\hline 9 & 0,01 & $-0,04$ & 0,09 & 0,03 & 1,03 & 0,46 & 0,97 & 0,55 & $\mathrm{HO}$ \\
\hline 8 & 0,01 & $-0,05$ & 0,12 & 0,03 & 1,03 & 2,41 & 0,90 & 0,00 & $\mathrm{H} 1$ \\
\hline 7 & 0,00 & $-0,10$ & 0,09 & 0,05 & $-0,07$ & $-0,44$ & 0,94 & 0,05 & $\mathrm{HO}$ \\
\hline 6 & 0,00 & $-0,07$ & 0,16 & 0,05 & 1,06 & 1,58 & 0,93 & 0,02 & $\mathrm{H} 1$ \\
\hline 5 & 0,00 & $-0,18$ & 0,11 & 0,05 & $-1,10$ & 4,36 & 0,91 & 0,01 & $\mathrm{H} 1$ \\
\hline 4 & 0,01 & $-0,14$ & 0,17 & 0,07 & 0,47 & $-0,06$ & 0,96 & 0,28 & $\mathrm{H} 0$ \\
\hline 3 & $-0,01$ & $-0,12$ & 0,12 & 0,05 & 0,07 & 0,40 & 0,97 & 0,55 & $\mathrm{H} 0$ \\
\hline 2 & $-0,01$ & $-0,12$ & 0,11 & 0,07 & 0,12 & $-0,92$ & 0,97 & 0,40 & $\mathrm{HO}$ \\
\hline 1 & $-0,01$ & $-0,14$ & 0,12 & 0,06 & 0,10 & $-0,59$ & 0,98 & 0,89 & $\mathrm{HO}$ \\
\hline 0 & $-0,01$ & $-0,25$ & 0,12 & 0,07 & $-1,19$ & 3,66 & 0,92 & 0,01 & $\mathrm{H} 1$ \\
\hline-1 & 0,00 & $-0,07$ & 0,11 & 0,04 & 0,21 & $-0,06$ & 0,99 & 0,93 & $\mathrm{H} 0$ \\
\hline-2 & 0,00 & $-0,06$ & 0,08 & 0,03 & 0,53 & $-0,16$ & 0,97 & 0,38 & $\mathrm{HO}$ \\
\hline-3 & $-0,01$ & $-0,10$ & 0,05 & 0,03 & $-0,44$ & $-0,04$ & 0,97 & 0,56 & $\mathrm{H} 0$ \\
\hline-4 & 0,00 & $-0,04$ & 0,05 & 0,03 & 0,15 & $-1,06$ & 0,95 & 0,16 & $\mathrm{H} 0$ \\
\hline-5 & 0,00 & $-0,11$ & 0,07 & 0,04 & $-0,61$ & 0,46 & 0,97 & 0,32 & $\mathrm{H} 0$ \\
\hline-6 & 0,00 & $-0,08$ & 0,05 & 0,02 & $-0,72$ & 2,91 & 0,93 & 0,04 & $\mathrm{H} 1$ \\
\hline-7 & 0,00 & $-0,04$ & 0,05 & 0,02 & 0,03 & $-0,45$ & 0,99 & 0,99 & $\mathrm{HO}$ \\
\hline-8 & $-0,01$ & $-0,07$ & 0,07 & 0,03 & $-0,05$ & 0,26 & 0,94 & 0,07 & $\mathrm{HO}$ \\
\hline-9 & 0,01 & $-0,02$ & 0,06 & 0,02 & 1,15 & 2,03 & 0,92 & 0,01 & $\mathrm{H} 1$ \\
\hline-10 & 0,00 & $-0,10$ & 0,04 & 0,03 & $-0,94$ & 3,54 & 0,90 & 0,00 & H1 \\
\hline-11 & 0,01 & $-0,06$ & 0,08 & 0,03 & 0,59 & 0,32 & 0,94 & 0,08 & $\mathrm{H} 0$ \\
\hline-12 & 0,00 & $-0,06$ & 0,09 & 0,02 & 1,68 & 10,57 & 0,77 & 0,00 & $\mathrm{H} 1$ \\
\hline-13 & $-0,01$ & $-0,03$ & 0,04 & 0,01 & 1,67 & 4,21 & 0,85 & 0,00 & $\mathrm{H} 1$ \\
\hline-14 & 0,00 & $-0,02$ & 0,05 & 0,02 & 0,99 & 1,77 & 0,93 & 0,02 & $\mathrm{H} 1$ \\
\hline-15 & 0,00 & $-0,06$ & 0,04 & 0,02 & $-0,94$ & 1,27 & 0,94 & 0,07 & $\mathrm{HO}$ \\
\hline-16 & 0,00 & $-0,02$ & 0,02 & 0,01 & $-0,13$ & $-0,67$ & 0,97 & 0,37 & $\mathrm{H} 0$ \\
\hline-17 & 0,00 & $-0,02$ & 0,05 & 0,01 & 1,20 & 4,88 & 0,90 & 0,00 & $\mathrm{H} 1$ \\
\hline-18 & 0,00 & $-0,05$ & 0,03 & 0,01 & $-1,84$ & 8,86 & 0,82 & 0,00 & H1 \\
\hline $\begin{array}{l}-19 \\
\end{array}$ & 0,00 & $-0,03$ & 0,03 & 0,01 & 0,14 & $-0,66$ & 0,97 & 0,52 & $\mathrm{H} 0$ \\
\hline-20 & 0,00 & $-0,02$ & 0,02 & 0,01 & 0,07 & $-0,43$ & 0,98 & 0,82 & $\mathrm{H} 0$ \\
\hline
\end{tabular}

Źródło: opracowanie własne na podstawie danych z investing.com oraz wyliczeń z wykorzystaniem programu Excel i Gretl. 
Dodatkowo przetestowano, korzystając z programu Gretl, normalność rozkładu badanych ponadnormatywnych stóp zwrotu. W tym celu wykorzystano test Shapiro-Wilka, czyli standardowy test do testowania normalności rozkładów, w tabeli uwględniono również wartości p-value, na podstawie których dokonano wyboru spośród hipotez. Hipoteza zerowa tego testu zakłada występowanie rozkładu normalnego dla badanej próby, natomiast hipoteza alternatywna zaprzecza (brak występowania rozkładu normalnego). W tabeli wyniki sugerujące brak podstaw do odrzucenia hipotezy zerowej zostały oznaczone jako H0, natomiast te wskazujące na hipotezę alternatywną - jako H1. Poziom istotności przyjęty podczas badania odpowiada standardom w naukach ekonomicznych, czyli wynosi 0,05 . Wartości wyszczególnione w tabeli, z uwagi na łatwiejszy odczyt, zostały zaokrąglone do drugiego miejsca po przecinku. Zauważyć można, że średnia ponadnormatywnych stóp zwrotu dla każdej spółki dla każdego dnia wokół zdarzenia (okres 20 dni przed zdarzeniem, zdarzenie i 20 dni po) oscyluje wokół zera. Wskazywać na to może też wartość minimalna oraz maksymalna (także ujęte w tab. 1), które również dla każdego dnia są bliskie zeru. Większość z wyliczonych średnich jest dodatnia, a oznaczać to może, że badane zdarzenie może tworzyć dodatkową wartość dla posiadaczy waloru (Perepeczo, 2010). Nie biorąc pod uwagę statystyki testowej Shapiro-Wilka można, kierując się skośnością i kurtozą, z pewnym błędem ocenić normalność rozkładu. Dla rozkładu normalnego, zgodnie z formułami, za pomocą których program Excel wylicza wskazane parametry, zarówno skośność, jak i kurtoza powinny być bliskie zeru, a znaczne odstawanie powyżej lub poniżej 0 świadczyć może na korzyść hipotezy o braku normalnego rozkładu - co zaobserwować można w tabeli. Dla tych dni wokół zdarzenia, dla których skośność i kurtoza okazują się mocno odstawać od zera, p-value przyjmuje niskie wartości - poniżej zakładanego poziomu istotności.

W związku z tym, że część z ponadnormatywnych stóp zwrotu wykazuje brak normalności rozkładu zdecydowano się na zastosowanie testu nieparametrycznego dla całego 41-dniowego okna zdarzenia. Zastosowanym testem jest test Corrado. Nie wymaga on spełnienia restrykcyjnych założeń odnośnie postaci rozkładu stóp zwrotu. Jest równocześnie jednym z najczęściej stosowanych tego typu testów w przypadku analizy zdarzeń (Fiszeder i Mstowska, 2011).

Statystykę testową wspomnianego testu wylicza się za pomocą poniższej formuly:

$$
T(u)=\frac{\frac{1}{N} \sum_{i=1}^{N}\left(K_{i, t}-\bar{K}\right)}{s(K)},
$$

gdzie:

$K_{i, t}-$ przyporządkowana ranga dla okresu $t$,

$\bar{K}-$ średnia z rang obliczana według formuły $\bar{K}=0,5+0,5 T$,

$s(K)$ - odchylenie standardowe rang wyliczane za pomocą wzoru: 
gdzie:

$$
s(K)=\sqrt{\frac{1}{T} \sum_{t=1}^{T}\left[\frac{1}{N} \sum_{i=1}^{N}\left(K_{i, t}-\bar{K}\right)\right]^{2}},
$$

$T$ - liczba okresów,

$N$ - liczba spółek.

Tabela 2. Wyniki testowania istotności ponadprzeciętnych stóp zwrotu

\begin{tabular}{|c|c|c|c|}
\hline Okres & $\begin{array}{c}\text { Statystyka } \\
\text { testowa }\end{array}$ & Okres & $\begin{array}{c}\text { Statystyka } \\
\text { testowa }\end{array}$ \\
\hline 20 & 0,01 & 0 & $-0,04$ \\
\hline 19 & $-0,21$ & -1 & 0,17 \\
\hline 18 & 0,16 & -2 & $-0,23$ \\
\hline 17 & 0,16 & -3 & $-0,37$ \\
\hline 16 & 0,36 & -4 & 0,15 \\
\hline 15 & 0,04 & -5 & 0,00 \\
\hline 14 & $-0,30$ & -6 & $-0,02$ \\
\hline 13 & $-0,07$ & -7 & 0,09 \\
\hline 12 & 0,09 & -8 & $-0,19$ \\
\hline 11 & 0,16 & -9 & 0,28 \\
\hline 10 & $-0,10$ & -10 & $-0,01$ \\
\hline 9 & 0,20 & -11 & 0,18 \\
\hline 8 & 0,34 & -12 & 0,13 \\
\hline 7 & $-0,05$ & -13 & $-0,34$ \\
\hline 6 & $-0,29$ & -14 & 0,02 \\
\hline 5 & $-0,05$ & -15 & 0,06 \\
\hline 4 & $-0,01$ & -16 & 0,07 \\
\hline 3 & $-0,22$ & -17 & 0,25 \\
\hline 2 & $-0,16$ & -18 & 0,18 \\
\hline 1 & $-0,31$ & -19 & $-0,09$ \\
\hline & & -20 & \\
\hline & & & -19 \\
\hline
\end{tabular}

Źródło: opracowanie własne na podstawie danych $\mathrm{z}$ investing.com oraz wyliczeń z wykorzystaniem programu Excel.

Tabela 2 prezentuje wyniki testowana istotności ponadnormatywnych stóp zwrotu wyliczonych za pomocą testu Corrado. Obliczenia zostały przeprowadzone za pomocą programu Excel. 
Hipoteza zerowa dla powyższego testowania mówi o braku istotnej reakcji, z kolei alternatywna o jej występowaniu. Statystykę testową w celu weryfikacji przyrównuje się do wartości krytycznych (alfa 0,01 - krytyczna wart. $=2,57583$, alfa 0,05 - krytyczna wart. $=1,95996$, alfa $0,10-$ krytyczna wart. $=1,64485)$. Jak widać z powyższej tabeli, żaden $\mathrm{z}$ wyników testowania istotności ponadprzeciętnych stóp zwrotu nie wskazuje istotnej reakcji rynku giełdowego na informacje o zamknieciu granic, czyli wokół 16 marca (dnia zero).

W celu przeprowadzenia dalszej analizy wyliczono również skumulowane ponadnormatywne stopy zwrotu, czyli CAR. Wyliczono je dla 5 dni, 11 dni, 21 oraz 41 dni wokół zdarzenia, czyli ponownie wokół 16 marca.

Tabela 3 prezentuje statystyki opisowe dla skumulowanych ponadprzeciętnych stóp zwrotu obliczonych wokół dnia ogłoszenia informacji. Ponownie wyliczono takie statystyki jak: średnią, wartość minimalną (min. wartość), wartość maksymalną (max. wartość), odchylenie standardowe (odch. stand.), skośność, kurtozę. Wymienione parametry zostały podobnie wyliczone za pomocą programu Excel. Dodatkowo przetestowano, korzystając z programu Gretl, normalność rozkładu badanych ponadnormatywnych stóp zwrotu. W tym celu wykorzystano test Shapiro-Wilka, w tabeli uwględniono również wartości p-value, na podstawie których dokonano wyboru spośród hipotez. Wszystkie skumulowane ponadnormatywne stopy zwrotu okazują się, według p-value oraz poziomu istotności, przyjętego odgórnie na poziomie 0,05 , mieć rozkład normalny. O możliwości przyjęcia hipotezy zerowej jako prawdziwej wskazywały również wartości skośności oraz kurtozy. Średnia ponownie oscyluje wokół 0 (wszystkie wyliczone średnie są ujemne, w przeciwieństwie do średnich wyliczonych dla ponadnormatywnych stóp zwrotu $A R$ ).

W związku z tym, że wyliczone skumulowane ponadnormatywne stopy zwrotu dla okresów 5 dni, 11 dni, 21 oraz 41 dni wokół zdarzenia mają rozkłady normalne, możliwe jest wykorzystanie testu parametrycznego, podanego poniższym wzorem (Gurgul, 2006):

$$
t=\frac{\overline{A R}}{\hat{s}\left(A R_{t}\right)} \sqrt{N}
$$

gdzie: $\overline{A R_{t}}$ - średnia i $\hat{s}\left(A R_{t}\right)$ - odchylenie standardowe ponadnormatywnych stóp zwrotu dla danych przekrojowych dla $N$ zdarzeń. 
Tabela 3. Statystyki opisowe dla skumulowanych ponadprzeciętnych stóp zwrotu obliczonych wokół dnia ogłoszenia informacji

\begin{tabular}{|c|c|c|c|c|}
\hline Nazwa spółki & $(-2,+2)$ & $(-5,+5)$ & $(-10,+10)$ & $(-20,+20)$ \\
\hline Acciona_ & 0,16 & 0,08 & 0,08 & 0,19 \\
\hline Acerinox & $-0,03$ & 0,00 & $-0,09$ & 0,03 \\
\hline $\mathrm{ACS}_{-}$ & $-0,39$ & $-0,29$ & $-0,22$ & $-0,06$ \\
\hline Aena_ & 0,03 & 0,01 & $-0,09$ & 0,05 \\
\hline Amadeus_ & $-0,09$ & $-0,04$ & $-0,10$ & $-0,08$ \\
\hline Arcelor & $-0,19$ & $-0,17$ & $-0,20$ & $-0,24$ \\
\hline Bankia_ & 0,11 & $-0,06$ & $-0,04$ & $-0,17$ \\
\hline Bkt_ & $-0,24$ & $-0,07$ & $-0,25$ & $-0,20$ \\
\hline BBVA & $-0,09$ & $-0,07$ & $-0,12$ & $-0,27$ \\
\hline CABK_ & $-0,06$ & $-0,01$ & $-0,05$ & $-0,18$ \\
\hline CLNX & 0,16 & 0,08 & 0,24 & 0,37 \\
\hline CIEA_ & $-0,19$ & $-0,05$ & 0,01 & 0,03 \\
\hline Enag & 0,15 & 0,08 & 0,01 & 0,11 \\
\hline ENCE_ & 0,02 & 0,01 & $-0,06$ & 0,07 \\
\hline Endesa_ & $-0,05$ & $-0,03$ & 0,10 & 0,14 \\
\hline FER & $-0,10$ & $-0,06$ & 0,09 & 0,15 \\
\hline SGREN & 0,19 & 0,17 & 0,20 & 0,22 \\
\hline GRLS_ & 0,24 & 0,29 & 0,34 & 0,29 \\
\hline IAG_ & $-0,48$ & $-0,53$ & $-0,60$ & $-0,73$ \\
\hline IBE & 0,09 & 0,07 & 0,11 & 0,19 \\
\hline ITX & 0,05 & 0,05 & 0,06 & 0,19 \\
\hline IDR_ & 0,01 & $-0,02$ & 0,00 & 0,04 \\
\hline $\mathrm{COL}_{-}$ & $-0,27$ & $-0,28$ & $-0,08$ & $-0,11$ \\
\hline MAP_ & 0,15 & 0,00 & 0,01 & 0,04 \\
\hline MASM_ & 0,00 & $-0,08$ & 0,03 & 0,29 \\
\hline TL5_ & $-0,06$ & $-0,09$ & $-0,07$ & $-0,04$ \\
\hline MEL_ & $-0,36$ & $-0,24$ & $-0,24$ & $-0,20$ \\
\hline MRL & $-0,09$ & $-0,22$ & $-0,27$ & $-0,17$ \\
\hline NTGY_ & 0,11 & 0,07 & $-0,01$ & $-0,05$ \\
\hline REE_ & 0,18 & 0,14 & 0,25 & 0,18 \\
\hline REP & $-0,13$ & $-0,14$ & $-0,01$ & $-0,14$ \\
\hline$\overline{S A B E}_{-}$ & $-0,09$ & $-0,20$ & $-0,27$ & $-0,34$ \\
\hline SAN_ & $-0,12$ & $-0,07$ & $-0,13$ & $-0,29$ \\
\hline TEF & 0,16 & 0,11 & 0,02 & $-0,03$ \\
\hline VIS & 0,27 & 0,23 & 0,31 & 0,36 \\
\hline Średnia & $-0,03$ & $-0,04$ & $-0,03$ & $-0,01$ \\
\hline Odch.e stand. & 0,18 & 0,16 & 0,18 & 0,22 \\
\hline Min. wartość & $-0,48$ & $-0,53$ & $-0,60$ & $-0,73$ \\
\hline Max. wartość & 0,27 & 0,29 & 0,34 & 0,37 \\
\hline Skośność & $-0,57$ & $-0,73$ & $-0,46$ & $-0,74$ \\
\hline Kurtoza & $-0,03$ & 1,73 & 1,61 & 1,56 \\
\hline SW & 0,96 & 0,96 & 0,96 & 0,96 \\
\hline P-value & 0,26 & 0,23 & 0,21 & 0,18 \\
\hline Normalność rozkładu & $\mathrm{H} 0$ & $\mathrm{H} 0$ & $\mathrm{H} 0$ & $\mathrm{H} 0$ \\
\hline
\end{tabular}

Źródło: opracowanie własne na podstawie danych z investing.com oraz wyliczeń z wykorzystaniem programu Excel i Gretl. 
Tabela 4. Wyniki testowania istotności skumulowanych ponadprzeciętnych stóp zwrotu

\begin{tabular}{|l|c|c|c|c|}
\hline CAR & $(-2,+2)$ & $(-5,+5)$ & $(-10,+10)$ & $(-20,+20)$ \\
\hline Statystyka $t$ & $-0,91$ & $-1,42$ & $-0,98$ & $-0,24$ \\
\hline
\end{tabular}

Źródło: opracowanie własne na podstawie danych $\mathrm{z}$ investing.com oraz wyliczeń z wykorzystaniem programu Excel.

Wartości krytyczne są ponownie identyczne, w związku z tym wynoszą: (alfa $0,01-$ krytyczna wart. $=2,57583$, alfa $0,05-$ krytyczna wart. $=1,95996$, alfa 0,10 - krytyczna wart. $=1,64485)$. Wynika z tego ponownie podobny wyniosek, co w przypadku ponadnormatywnych stóp zwrotu $A R$ - badanie wykazało, że nie nastąpiła istotna reakcja rynku giełdowego w Hiszpanii na informację o powrocie kontroli granicznych. Podsumowując, zarówno analiza $A R$ jak i $C A R$ wskazuje wyraźnie na brak istotnej reakcji rynku giełdowego w Hiszpanii.

\section{PODSUMOWANIE}

Z powyższych rozważań wynika, iż analiza zdarzeń jest niewątpliwie przydatnym narzędziem, w szczególności w badaniach przeprowadzanych w zakresie finansów behawioralnych, gdzie główną rolę odgrywają przede wszystkim zachowania i reakcje różnych podmiotów gospodarujących, czy też inwestorów. Przeprowadzona szczegółowa analiza zdarzeń na ponadnormatywnych, jednookresowych, logarytmicznych stopach zwrotu oraz skumulowanych, ponadnormatywnych, jednookresowych logarytmicznych stopach zwrotu dla zdarzenia, jakim jest zamknięcie granic Hiszpanii (16 marca 2020 roku) wykazała brak istotnej reakcji inwestorów na wspomniane zdarzenie - upublicznioną informację o zamknięciu owych granic kraju, zarówno dla $A R$, jak i $C A R$. W związku $\mathrm{z}$ tym postawiona hipoteza nie została pozytywnie zweryfikowana. Stanowi to interesujący przypadek, przeczący niejako stawianej przez ekonomistów behawioralnych tezie o nieracjonalności zachowań inwestorów na rynku kapitałowym, gdyż panika na tym rynku nie wybuchła, jak można by się spodziewać sugerując się tą teorią, wobec czego nie miała miejsce gwałtowna reakcja rynku powodowana nieracjonalnym strachem przed załamaniem. Jednocześnie sytuacja ta poddała w wątpliwość hipotezę rynku efektywnego, twierdzącą jakoby sytuacja na rynku kapitałowym oraz ceny aktywów stanowiły idealne odzwierciedlenie informacji dostępnych publicznie. Informacja o zamknięciu granic była podana do ogólnego dostępu, a zatem w świetle tejże hipotezy dziwi fakt, iż nie odnotowano żadnej istotnej reakcji na tę informację. Warto powtórzyć w przyszłości badanie biorąc pod uwagę inne państwa bądź inne szczególne wydarzenia, istotnym mogłoby być powtórzenie badania biorąc pod uwagę Chiny, 
czyli zalążek rozprzestrzeniania się wirusa SARS-CoV-2. W artykule w sposób przejrzysty przedstawiono również metodologię badań, co może się przysłużyć dla zainspirowania innych autorów.

\section{BIBLIOGRAFIA}

Fama, E.F. (1970). Efficient Capital Markets: A Review of Theory and Empirical Work. Journal of Finance, 25(2),

Fiszeder, P. i Mstowska, E. (2011). Analiza wpływu splitów akcji na stopy zwrotu spółek notowanych na GPW w Warszawie. Modelowanie i prognozowanie gospodarki narodowej. Prace i Materiały Wydziału Zarządzania Uniwersytetu Gdańskiego, 4/8.

Gurgul, H. (2006). Analiza zdarzeń na rynkach akcji. Wpływ informacji na ceny papierów wartościowych. Kraków: Oficyna Ekonomiczna.

Investing, https://pl.investing.com/indices/spain-35 [dostęp: 21.11.2020].

Kabaciński, B. (2013). Ocena efektów fuzji i przejęć na podstawie analizy nadwyżkowych stóp zwrotu. Zarzadzanie i Finanse, 11(2) cz. 4.

Kahneman, D. and Tversky, A. (1979). Prospect Theory: An Analysis of Decision under Risk. Econometrica, XLVII.

Keynes, J.M. (2011). Ogólna teoria zatrudnienia, procentu i pieniądza. Warszawa: Wydawnictwo Naukowe PWN.

Kujawa, S. i Ostrowska, E. (2016). Analiza zdarzeń i jej zastosowanie w finansach behawioralnych. Finanse, Rynki Finansowe, Ubezpieczenia, 4(82) cz. 2.

Lisicki, B. (2018). Wpływ uwolnienia kursu franka szwajcarskiego na krótkoterminowe stopy zwrotu z notowań akcji banków na GPW w Warszawie. Przedsiębiorstwo \& Finanse, 1.

Mitchell, M.L. and Stafford, E. (1999). Managerial decisions and long-term stock price performance. CRSP Working Paper, 453.

Orlik, K. (2017). Makroekonomia behawioralna. Jak wyjaśniać zjawiska makroekonomiczne z wykorzystaniem ekonomii behawioralnej. Warszawa: CeDeWu.

Perepeczo, A. (2010). Analiza zdarzenia i jej zastosowania. Zeszyty Naukowe Uniwersytetu Szczecińskiego nr 632: Finanse, Rynki Finansowe, Ubezpieczenia, 33.

Schabek, T. (2016). Czynniki behawioralne i fundamentalne a stopy zwrotu z akcji rynków wschodzacych. Łódź: Wydawnictwo Uniwersytetu Łódzkiego.

Sudarsanam, S. and Mahate, A.A. (2003). Glamour acquirers, method of payment and post-acquisition performance. The UK evidence. Journal of Business Finance \& Accounting, 30.

Thaler, R. (2018). Zachowania niepoprawne. Tworzenie ekonomii behawioralnej. Poznań: Media Rodzina.

Zielińska, E. i Ostrowska, E. (2013). Uwarunkowania behawioralne decyzji inwestycyjnych. Zarzadzanie i Finanse, 11(2) cz. 4. 